\title{
COMPUTERISATION OF THE ICELANDIC STATE AND MUNICIPALITIES
}

From 1964 to 1985

\author{
Oddur Benediktsson, \\ Jóhann Gunnarsson, Egill B. Hreinsson, Jakob Jakobsson, \\ Örn Kaldalóns, Óttar Kjartansson, Ólafur Rósmundsson, \\ Helgi Sigvaldason, Gunnar Stefánsson, and Jón Zophoniasson \\ 1. Benediktsson, University of Iceland; oddur@hi.is \\ 2. Gunnarsson, Ministry of Finance; johann.gunnarsson@fji.stjr.is \\ 3. Hreinsson, University of Iceland; egill@hi.is \\ 4.Jakobsson, Marine Research Institute (retired); jak-mar@xnet.is \\ 5. Kaldalóns, Nýherji; kaldalon@nyherji.is \\ 6. Kjartansson, Skýrr (retired); ottar@heima.is \\ 7. Rósmundsson, Reiknistofa bankanna; Olafur.rosmundsson@rb.is \\ 8. Sigvaldason, Consultant; helgis@hi.is \\ 9. Stefánsson, University of Iceland; gunnar@hi.is \\ 10. Zophoniasson, Internal Revenue Directorate; jon.zophoniasson@rsk.is
}

\begin{abstract}
The paper relates how some key IT applications developed in Iceland following the introduction of the first computers in 1964. The key applications treated are the National Register of Persons, real estate assessment, financial systems, centralised processing of bank checks, fish stock abundance computations, IT in fish processing plants, the control of hydroelectric power stations, and the challenge of adopting the Icelandic alphabet to the use of computers.
\end{abstract}

Key words: Computers and government, government accounting 


\section{INTRODUCTION}

The history of electronic data processing in Iceland began in 1949 when Hagstofa Íslands (Statistical Bureau of Iceland) obtained the first numerical Unit Record (punched card) equipment to facilitate the processing of import and export transactions. The government established the National Register of Persons in 1952 based upon the 1950 census and a special nationwide census taken in 1952.

Skýrr (Skýrsluvélar ríkisins og Reykjavíkurborgar - The Icelandic State and Municipal Data Center) was established 1952 by an initiative from Hagstofa Íslands, Rafmagnsveita Reykjavíkur (Reykjavík Electric Power Utility), and the Practitioner General of Iceland. It enhanced the existing data processing equipment to handle alphabetic data and then used it to mechanise the National Register of Persons amongst other applications. IBM Unit Record equipment was in use for the first twelve years (Kjartansson 2002.)

The first electronic computers came to Iceland in 1964 as Skýrr obtained an IBM 1401 computer and the University of Iceland an IBM 1620 computer. In the 1960s, the unofficial policy of the government was that all administrative computation should be centralized at Skýrr and that the scientific, engineering, and educational computing should take place at the newly established Computing Centre of University of Iceland. In the early days, computers were quite costly and difficult to operate and maintain. Furthermore, only few persons had the expertise to develop and maintain computer applications. The advent of "inexpensive" minicomputers in the 1970 s changed all this. The monopoly was broken and many larger concerns obtained their own computers such as DEC PDP-8, PDP-11, and IBM System/3. IT system development became common knowledge. In 1980 the University of Iceland acquired a VAX 11/750 system and the usage of interactive system development was realized there. Aside from the equipment already mentioned electronic office equipment or computers from Olivetti, Kienzle, Burroughs, Wang, and others was imported and fierce competition existed amongst the importers.

\section{SKÝRR}

Skýrr came into existence in 1952 through a cooperative effort between the Icelandic State and the City of Reykjavík. The main purpose was to share the costs of operating a data centre with IBM Unit Record equipment for administrative data processing applications. They employed Unit Record equipment for the first twelve years. Skýrr obtained an IBM 1401 computer 
in 1964. It had $4 \mathrm{~K}$ core memory (see Appendix) and they used punched cards as data media. This system was a direct extension of the Unit Record equipment but with the advent in 1968 of an IBM 360/30 with tape and disk stations Skýrr started to convert from the punched cards to the magnetic tapes and disks as storage and processing media.

\subsection{Computers at Skýrr}

The number of applications housed at Skýrr grew rapidly in the first years. Some of the applications were based directly on the National Register of Persons such as the voting registers, taxation applications as well as invoicing for the various utilities (i.e. electricity, telephone, thermal water, and state radio). It established a vehicle registration register as well as a real estate register together with real estate assessments, salary systems, and other operations. To meet the processing needs, Skýrr updated progressively its computer configuration. Figure 1 shows an example of a proposed computer configuration at Skýrr in 1974.

By 1985 Skýrr was using two IBM 4382-2 mainframes. The number of employees at Skýrr was five in 1955. It had reached 18 in 1965, 64 in 1975, and 122 in 1985 . These figures exemplify the escalating increase in computer usage in the early years.

The software development tools used at Skýrr followed the generations of computers employed. During the IBM 1401 usage (1964-68) programs were written in the 1401 Symbolic Programming System (SPS). With the advent of the IBM $360 / 30$ system, the programming languages Assembler, RPG and PL/I came into use and greatly facilitated the software development. In 1982, the Adabas data base system was in use together with the fourth generation language Natural.

\subsection{First attempts at teleprocessing}

The year 1973 marked the first steps towards teleprocessing at Skýrr. Then the University of Iceland gained access to Skýrr's IBM 370/135, running the APL programming system over remote terminals. The university APL application was not successful and the university abandoned it after 3 years. The main reason for the failure was limited processing capacity in the 370 computer, which had $96 \mathrm{~K}$ of memory. A year later the Reykjavík City Hospital installed a terminal for RJE (Remote Job Entry) connected to the IBM computer at Skýrr to facilitate data processing for the clinical laboratory at the hospital. They punched in cards for requests for laboratory tests and the test results and then processed them over night when workload was low at Skýrr. The next morning various working lists and 
printed reports were ready at the RJE terminal. Subsequently the everincreasing need for teleprocessing was to have a profound effect on the telephone infrastructure; that is, teleprocessing led to the development of both the connections and equipment inside Iceland as well as the equipment connecting Iceland to other countries.

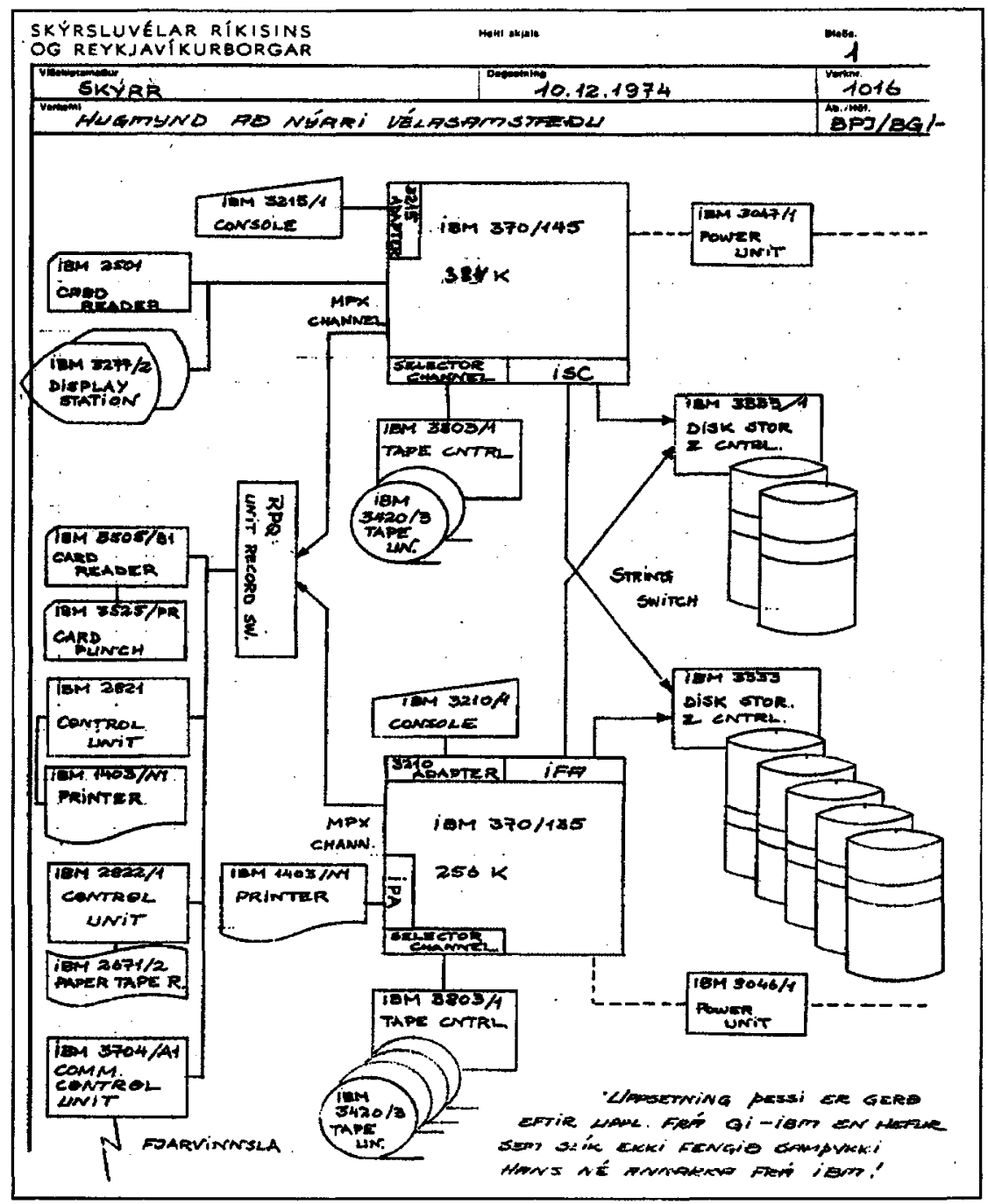

Figure 1. A diagram of proposed computer configuration of Skýrr in 1974 


\section{COMPUTERS IN THE ICELANDIC ADMINISTRATION}

Some of the key computer applications for the Icelandic state in the early days centred on the National Register of Persons, taxation, accounting, budget planning, and real estate assessment.

\subsection{The national register of persons}

By 1956, the government established the National Register by law for persons and in 1969 for firms. The register evolved from the original punched card system to a computerised system in the 1960 s and by 1985 , it had become an online system reflecting the status of the population on a daily basis. The first application for the register was to preprint tax returns in the year 1954. The original usage of the register was for population tracking, for use as a voting register, for official administration, for medical research, and for population statistics (Bórhallsson and Zóphaníasson 1985 and Kjartansson 2002). The Personal Identification Number used was composed of the birth date of the person concerned as nine digits DDMMYYNNH (date, month, year, sequential number within the date, and year hundred i.e. 8 and 9). With the advent of the computers, they added a check digit, making the PIN a ten-digit number. This number permeates all data processing in Iceland concerning persons and firms. They use it as identification in official administration, schools, hospitals, pharmacies, banks, on driver licenses, credit cards, and other related areas.

\subsection{Computers and the tax authorities}

The first task performed by Skýrr for the tax authorities in Reykjavík was printing names and addresses on tax declaration forms in 1954, using the punch card based National Register of Persons as a basis. Later that year, they collected taxes and prepared related documentation for the tax collectors. Within few years, they computerized all other tax districts in this manner. After its establishment in 1962, the Directorate of Taxes assumed responsibility for the development of computerised tax systems.

When the first electronic computers arrived in 1964, the processing methods of the Unit Record era were transferred to the computer with minimal change; the Unit Record was the name given to the punched card. This immediately increased speed, but did little for the part of the process that required deskwork. On the other hand, one of the first labour-saving features in the tax processing system came in 1978 when it became possible to compare automatically employees' tax declarations with employers' 
statements of paid salaries. As the data-entry devices of those days (i.e. card punches and later diskette recorders) were quite expensive, it was not considered economical to install such devices in the small tax offices in the countryside. The result was that they performed most of the data entry in Reykjavik. In 1982, the tax offices around the county were equipped with inexpensive personal computers (Tandy TRS80 with simple file transfer programs) programmed for data entry and so the workload was distributed out to the local offices.

\section{THE GOVERNMENT ACCOUNTING AND PLANNING SYSTEM}

\subsection{The expenditure accounting system}

The Treasury started using computers in 1978. That year they put to use a simple batch based expenditure accounting system programmed in RPG to run on the Skýrr computer. Output was in the form of printed lists with no possibility for on-screen viewing of data. This was primarily historic accounting with very limited management information. In 1983, they decided to take up online processing. For that purpose, they purchased a complex system for financial accounting called the Management Science of America (MSA). It turned out that the accounting key of MSA, its arrangement, and in fact, various other features did not fit Icelandic requirements; the system proved cumbersome if not impossible to adapt.

In 1985, they discontinued the use of the MSA system. Instead, they decided to develop a new system from scratch. This new system, called BÁR (Bókhalds- og Áætlanakerfi Ríkisins), went into service in 1986 and was considered a success by its users right from the beginning. In the design, they placed a heavy emphasis on error checking and reconciliation of transactions. There were provisions for on-screen management information, both ad hoc summary screens from almost every conceivable view and comparison against budget; this was crucial in the Administration as the State budget dictates what one can spend. This system had built-in teleprocessing possibilities. The BÁR accounting system has undergone considerable changes and has had new features added through the years. The Oracle e-business suite, a new and modern financial system, replaced it during 2003. 


\subsection{The revenue accounting system}

Online data processing had a slow and cautious start in the central administration. They designed a revenue accounting system at Skýrr, which became operative in 1979 . This was the first online system used in the administration. This event also marked the beginning of usage of SNA (Systems Network Architecture, the communications protocol developed by IBM in the early seventies) in Iceland. Initially, they installed remote terminals at the Reykjavik Tax Collector's Office (Gjaldheimtan i Reykjavik). At this time, the municipalities owned and operated the tax collector's offices in Reykjavík and five other townships, collecting for both local and central authorities. Elsewhere, these operations were separate. In 1981, four additional tax districts, Akureyri, Kópavogur, Hafnarfjörður, and Keflavik became part of the online system. The remaining tax districts went online during the subsequent years.

\subsection{Real estate assessment}

In 1966, work began to computerise the real estate assessment process. The availability of computers clearly showed the benefit of automating registration, maintenance, and printing of the description and assessment values. At the same time, the opportunity was seized to automate the process of assessing residential buildings. A model was developed that contained dozens of parameters of an assessment record describing the structure and state of the building and computed an estimated building cost. This value was depreciated according to the age of the building and adjusted it to the estimated market value. The model was developed in FORTRAN II for the IBM 1620 and ran it initially at the University of Iceland Computing Centre in 1970. The city planners also developed initially a unique property reference number (block number) for the City of Reykjavík and its surroundings; the numbers referenced the land and buildings from the first planning stages. A revised model became operative in 1976 based on a set of unit prices collected by the Central Statistical Bureau on a continuous basis in order to compute the "building cost index" and a model built at the Building Research Institute for combining the unit prices into cost of building units. The new assessment model was implemented in FORTRAN IV for a Data General minicomputer. Samples of real estate sales and later registration of all sales became part of the process on ongoing basis and used to compute the relationship between depreciated building costs and market values. These models have served as the basis for the levy of property tax and for planning purposes as well as a registry for real estate properties and their ownership. 


\subsection{Municipalities in Iceland}

In 1970 the municipalities in Iceland (except Reykjavík) were using Burroughs General Ledger machines to account for the local income tax. Each taxpayer had his or her own ledger card where the payments were recorded. The Skýrr centre (see above) calculated the individual tax assessment and the property rates as computed from the computerised real estate assessment (see above).

The municipalities started to cooperate in the early 70 's to find a common solution to their need for improved data processing. The minicomputers had appeared on the scene, making it feasible to manage the tax collection locally. The solution adopted was based on standard software from IBM, termed the "Taxpayer's Account" system (gjaldendabókhald), running on an IBM System/32. The state taxes and property rates were computed centrally by Skýrr with local taxes and adjustments performed in the Taxpayer's Account system. The Taxpayer's Account systems were in use well into the 1980s the and were then all centralised at Skýrr.

\section{REIKNISTOFA BANKANNA}

The larger banks in Iceland started to use punched cards systems for data processing in the 1950 s and some had acquired computers by the late $1960 \mathrm{~s}$. The growing use of cheques was rapidly becoming an unsolvable task for the banks using traditional methods.

In the year 1970, the public banks in Iceland embarked on cooperation project to find a common solution to their core data processing needs and in particular to the mounting problem of clearing cheques. Subsequently Reiknistofa bankanna (Icelandic Banks Data Centre) was established and the common processing started in 1975 after an extended period of training and preparation. The first application involved processing of cheques using Optical Character Reading of numbers imprinted at the bottom edge of the cheques. By 1976, a bank customer could make a cheque transaction in any bank office and the bank would record the transaction into the relevant account with electronic document interchange and with the account balance entered into the account of each Bank at the Central Bank of Iceland. Thus, every evening, RB returned the same results as obtained earlier with the "spot checks" of the Central Bank. The spot checks had taken place three to five times a year at considerable cost and effort. The level of automation achieved by this was unprecedented worldwide as best known. The volume of entries in the cheque system during the first complete operating year was 13.6 million transactions. 
By 1981, the electronic booking of transactions and electronic transfer of funds was in effect for all of Iceland. Bank customers could then cash a cheque from any bank at any branch in the country and the clearing was instant. This put an end to the fraudulent practice of covering one bad cheque by the issue of another. The first expedition system went online in 1982, when the cheque system and the main general ledger system developed by the Industrial Bank were incorporated and integrated with other applications at RB. The following year saw negotiations with computer companies for the purchase of online front-desk equipment, and the Icelandic Savings Banks' Association became a full partner. Most of the electronic records of RB became accessible for online queries in 1984. The first online teller system was taken into use in 1985 in the LandsbankiBreidholt branch and by 1987 paper-free payment exchanges were affected in the Reykjavík metropolitan area.

In the year 1985, the total number of transactions in the common applications of Reiknistofa bankanna was 52.4 million records. The same year the number of employees reached 81 . The computer system used was an IBM-4381 mainframe, IBM-DOS operating system, using PL/I as the main programming language. Two years later the IBM-MVS operating system replaced the DOS requiring major updating of all systems and applications. In 1987, central OCR reading of cheques ceased at RB as the online teller terminals recorded all the required data.

\section{SCIENTIFIC COMPUTING AND SOFTWARE DEVELOPMENT METHODS}

The scientific and engineering community in Iceland started to use the first computer at the University of Iceland in 1964, as soon as it became operative. Some scientists had already learned to use computers at universities in other countries. A steady stream of FORTRAN II courses became available locally. Within a year or two, they wrote or acquired a number of applications from the IBM Program Library or other sources. From the start, they conducted research on software development methodologies (Benediktsson 1967, 1974, 1977.) Meteorologists, astronomers, geophysicists, fish- and livestock researchers, medical researchers, statisticians, and many others brought in their programs and data to execute at the University Computer Centre and to seek expert assistance. On the engineering side, the use of the computer proved particularly advantageous for surveyors and naval architects with their needs for massive computations. They built and simulated a number of operational research models to optimise the control for water reservoirs for hydroelectric power 
stations and to find the optimum size of a trawler in Icelandic waters. For further information, see Magnusson 2003.

\section{COMPUTING THE HERRING STOCK}

The Marine Research Institute started using the punch card system in the late 1950s. Herring tagging was the very first fisheries research data transferred to this system. The most important herring fishery at Iceland traditionally took place during the summer off the north coast, based on the so-called "Norðurlandssild"; that is, the herring off the north coast of Iceland. When repeated attempts to locate this herring outside the summer season failed, Árni Friðriksson $(1935,1944)$ suggested that this herring migrated to Norway each autumn to spawn in early spring. According to this theory, it followed that the well-known winter and spring herring fishery off the west coast of Norway was on the same herring stock as the summer fishery off Iceland. In order to test these revolutionary ideas, Icelandic and Norwegian scientists started mass tagging of herring in 1948. By the late 1950s, Iceland had tagged about 100.000 herring and Norway tagged about double that number. The new Automatic Data Processing (ADP) methods greatly facilitated the processing of these data. The system quickly verified Friðriksson's ideas on trans-oceanic migrations between Norway and Iceland. In addition, they used the tag-returns to assess the abundance of this internationally important herring stock. They presented the results at an ICES Herring Symposium in 1961 and formally published their findings two years later (Dragersund and Jakobsson 1963). Thus, primarily due to tagging and the new ADP methods, it proved possible to elucidate the decline of the stock from the high level of twelve million tons during the early 1950 s to five million tons in 1959. Severe scepticism surrounded these results at the time, but later assessments have verified how accurate these first abundance estimates were as shown in Table 1.

Table 1. Abundance estimates of adult Norwegian Spring spawning herring in millions of tons for the years 1953-1959 based on the results from tagging experiments at Iceland and ICES "best estimates" based on the Virtual Population Analysis (VPA) method.

\begin{tabular}{ccc}
\hline Year & $\begin{array}{c}\text { Tagging Results } \\
1961\end{array}$ & $\begin{array}{c}\text { VPA } \\
1999\end{array}$ \\
\hline 1953 & 12.5 & 12.0 \\
1954 & 12.2 & 9.7 \\
1955 & 13.9 & 14.7 \\
1956 & 12.0 & 13.5 \\
1957 & 9.3 & 10.9 \\
1958 & 6.6 & 9.8 \\
1959 & 5.0 & 7.6 \\
\hline
\end{tabular}


As mentioned above, the first computers came to Iceland in 1964 when Skýrr obtained an IBM 1401 computer and the University of Iceland an IBM 1620. Prior to this, the landings of the major species of fish had been sampled for several decades with regard to various biological and biometric parameters. When the appropriate programs were in place, the new computers tabulated these accumulated data and combined them to corresponding catches of the fishing fleet the annual catch in numbers of each year class was calculated.

The late 1960s saw the introduction of a new method, the so-called Virtual Population Analysis (VPA), for assessing fish stock abundance. The basic data required for VPA were already available due to the employment of the IBM 1620 and 1401 computers and the new method could be applied such as for the cod and herring stock size estimation at Iceland already for the beginning of the 1970s. Subsequently in the years up to 1980 , computer programs routinely estimated the abundance of fish stocks interactively on PDP-11 computers, eventually running Unix variants. In 1984-85, the Icelandic marine scientists obtained access to mail and news feeds when the Marine Research Institute first established a dial-up link to Sweden and subsequently became the first Iceland backbone-link to the predecessor of the internet. This quickly developed into an invaluable link to several key colleagues and sister institutes worldwide.

\section{FISH PROCESSING PLANTS}

Fishing and the fish processing industry form the basis of the Icelandic economy. Around the year 1970, fish processing plants started paying a bonus to employees for efficiency in production and utilization of raw material. In the early 1970 s, the company Rekstrartækni s/f computerised the bonus calculation for the larger fish processing plants in Iceland. In 1972, Rekstrartækni purchased an IBM System/3 system and IBM Iceland assisted in writing RPG programs for a salary system. They started servicing the processing plant Î́sbjörninn (with close to 200 employees), and were so successful that soon they had 16 plants to serve. They arranged monthly meetings with the plant managers to coordinate this new technique. The managers took care not to disclose any critical information about their plants to the competitors with the remarkable exception of the "contribution margin" and the Rekstrarækni staff had to sign a non-disclosure agreement. Based on the operative data obtained in the plants the utilisation of the raw material was computed and measures taken to improve it. As a result the utilisation of the raw material for cod, for example, increased from $36 \%$ to 
$42 \%$ in the period 1974 to 1980 resulting in $18 \%$ increase in packed products that yielded 5400 ton addition in the total production.

In 1981 Rekstrartækni had four large IBM System/34 computers, when they purchased one IBM System $/ 38$ to take over all their data processing. By then they were by far the largest mid-range computer installation in Iceland. Subsequently the fish processing plants began purchasing their own midrange computers and started running their own salary and accounting systems.

\section{LANDSVIRKJUN}

One of the earliest minicomputers based on real-time control applications in Iceland became operational in late 1974 in Landsvirkjun (The National Power Authority). Leeds \& Northrup manufactured the "Supervisory Control and Data Acquisition (SCADA) System" for Landsvirkjun and installed it to control and monitor hydroelectric power stations and substations in the power system, which at the time covered the Southwestern part of Iceland. The system, labelled the Conitel 2050, consisted of a computer based master station and several hardwired remote stations. The master station was based on a dual configuration of a Lockheed MAC-16 minicomputer. They installed a similar system at the Reykjavik Municipal Electric Works. Both these systems were in operation well into the eighties.

\section{COMPUTERS AND THE ICELANDIC ALPHABET}

The basic character set for early data processing consisted of the 26 characters in the English alphabet together with the ten decimal numerals. The Icelandic language has ten letters that do not occur in English as shown Aá $E_{\mathfrak{a}}$ Đo here. This really means twenty, when one considers both Eé lí Ó ó Ö̈ upper and lower case letters. This, together with the tiny Uú Ý $\mathbf{~ P b}$ added workload and it took ingenuity to make printed alphanumeric data look reasonable on printed output and display devices. Throughout the Unit Record period $(1952$ - 1964), the repertoire was limited to 37 or 38 characters, which meant that people had to make compromises.

Out of the ten additional Icelandic letters, four were considered essential for printing understandable names, namely $\mathrm{\oplus}, \mathrm{D}, \mathbb{E}$ and $\mathrm{O}$. The remaining six are vowels written with acute accents. In the tight situation, the 
compromise was to accept the plain unaccented vowels as substitutes as it would normally not cause misunderstanding. It is clear that not everybody was happy, though, to have their names "mutilated" in official documents. By dropping $\mathrm{Q}$, which is not used in the Icelandic alphabet, and using the same glyph for 1 (one) and I as well as the same modified glyph for 2 and $Z$, this was possible.

The IBM 1401 computer was capable of handling 48 characters, as was the first generation of the IBM 1403 printers. This meant that it was no longer necessary to have the same glyph stand for two different letters/digits. However, there was still only room for two of the accented Icelandic letters and the selection was the characters $A$ and É. On hindsight, it was of course rather useless to take on only two of the six accented letters.

A revolution can be said to have taken place with the Extended Binary Coded Decimal Interchange Code (EBCDIC), introduced by IBM with its 360 computer line. This was an eight-bit code with 256 different code points and thus plenty of room for letters specific to other languages than English. Therefore, with the IBM 360/30, Iceland obtained the capacity for a full Icelandic alphabet without sacrificing anything else.

It is a remarkable coincidence that at almost the same time the American Standards Association (ASA, which later changed its name to the American National Standards Institute, ANSI) published the first version of it's 7 bit ASCII code (American Standard Code for Information Interchange), which was adapted by all American computer manufacturers except IBM (1). To adapt ASCII to languages using accented letters there were ten open code points for national adaptation. In Iceland, we used a version using a socalled floating accent where the accent was actually stored separately, ahead of the letter on which it was supposed to sit. This solution caused difficulties when sorting. In addition, one needed a special adaptation to most printers to combine the two. This solution was incompatible with EBCDIC.

The 7-bit limitation was a general problem in Europe and many other countries that forced an extension to eight bits. In the seventies, the European Computer Manufacturers Association (ECMA) started working on an 8-bit code table that would address the needs of the various European and other languages for which ASCII was not sufficient. Wilhelm Friedrich Bohn, the IBM representative in the ECMA working group on code tables and keyboards (2), proposed a code table. ECMA released this table, nicknamed the Bohn Code, in 1985 as the ECMA-94 standard. The ISO adopted it and today we know it as ISO 8859-1 or Latin-1 code.

Mr. Bohn was familiar with the requirements of the Icelandic language. Since no other serious contestant for the code points was in question at that time (contrary to what later happened (3)), the complete Icelandic alphabet became part of his proposal, later known as the Latin-1 code page. The 
Icelandic government has duly acknowledged Mr. Bohn's contribution to the Icelandic information society.

As far as personal computers, the IBM PC and its clones that were capable of handling eight-bit character sets appeared on the Icelandic market. Each importer created its own version of an Icelandic code table. By 1985 or so, at least four versions were in circulation, plus one for the Apple Macintosh, causing difficulties in exchanging data. Jóhann Gunnarsson, then manager of the University Computing Centre in Reykjavik, called some meetings between the importers and a number of key users. Eventually, he proposed a compromise code table, sometimes named the JG Code; all PC and PC clone importers eventually adopted this code. Jóhann's attempts at persuading the Apple community to adopt the same code points for the Icelandic letters were not successful, however.

In due time, the JG Code was gradually replaced by IBM's Code Page 850 , which, as far as placement of the twenty extra Icelandic letters is concerned, is identical to ISO 8859-1.

\section{CONCLUSIONS}

In this paper, we have discussed the onset of the Information Age in Iceland. The applications that we selected for discussion have been instrumental in transforming Iceland from a rather backward society at the end of the Second World War to a modern society of today. Although Iceland has a very small population (about 230.000 persons in 1980), the degree of administrative computerization in Iceland is comparable with that of many larger Western nations. In a small country, the complexity of application can be brought under control and because of that, development costs are minimal. Stefán Ingólfsson has observed that the cost of developing a system in Iceland can be as small as one fifth or even one tenth of the cost of developing equivalent system in any of the other Scandinavian countries (Kjartansson 2002.)

\section{REFERENCES}

1. Benediktsson, O. 1967. "Fortran II málið fyrir IBM 1620 rafreikninn." Kennslukver, Reiknistofnun Háskólans, $58 \mathrm{p}$

2. Benediktsson, O. 1974. "Forritunarmálin ALGOL, FORTRAN og PL/I", Tímarit VFÍ, 86-88.

3. Benediktsson, O. 1977."Sequential file processing in Fortran IV", Software Practice and Experience 7, 655-658. 
4. Friðriksson, A. 1935. "Tilraunir til síldveiða við Suðurlandið á varðskipinu Pór vorið $1935 "$ " in the Icelandic.) Agir, vol. 28 pp.125-132.

5. Friðriksson, A. 1944. "Norðurlandssildin (The Herring off the North Coast of Iceland, in Icelandic with an extended English summary)." Rit Fiskideildar no. 1, 388 p.

6. Dragersund, O. and Jakobsson, J. 1963, "Stock Strengths and Rates of Mortality of the Norwegian Spring Spawners as Indicated by Tagging Experiments in Icelandic Waters." Rapp. Et Proc. Verb. Vol. 154, pp 83-90.

7. Kjartansson, Ó. 2002. "Upplýsingaiðnaður í hálfa öld." Skýrr hf.

8. Magnússon, M. 2003. "The advent of the first general purpose computer in Iceland and its impact on science and engineering." History of Nordic Computing, Trondheim, 2003.

9. Sigvaldason, H. and Tulinius, H. 1980. "Human Health Data from Iceland" Banbury Report 4, Cold Spring Harbor Laboratory, 1980.

10. Pórhallson, J.P and Zóphoníasson, J. 1985. "Tölvuvinnsla Hagstofunnar." Klemensar bók. Afmælisrit, Félag viðskiptafræðinga og hagfræðinga, Sigurður Snævarr ritstjóri.

\section{ENDNOTES}

(1) Steven J. Searle. A Brief History of Character Codes in North America, Europe, and East Asia http://tronweb.super-nova.co.jp/characcodehist.html

(2) TrueType Fonts, http://www.norasoft.de/tt-fonts.html

(3) Turkey, for instance, has tried to persuade the standards community to exchange at least two of the Icelandic letters in ISO 8859-1 with letters from the Turkish alphabet.

\section{APPENDIX}

\section{Magnetic Core Memory}

The IBM 1401, 1620, and 360/30 computers mentioned earlier were all equipped with magnetic core memory, a much more compact and reliable technology than earlier vacuum tubes and mercury delay lines. Jay Forrester, who was head of the Whirlwind computer project, invented core memory at MIT in the late 1940s. IBM then licensed the technology and core memory became commonplace in much of the first and second-generation of IBM computers. Semiconductor memories largely replaced magnetic cores in the 1970 s, but they remained in use for many years in mission-critical and high-reliability applications. The Apollo Guidance Computer, for example used core memory, as did the early versions of the Space Shuttle. (Source: http://web.mit.edu/6.933/www/core.html)

Magnetic core memory had some interesting features. For instance, it did not need constant current to keep its contents. In some cases, after a night's rest it was possible to start with the program and data from the previous day. Also, it emitted electromagnetic waves, which could be detected in the near vicinity of the memory unit. It was discovered that a certain way of programming the IBM 1401 computer made it possible to play some simple 
melodies that could be heard in a radio receiver put on top of the memory unit. A sequence of NOP (No operation) instructions dictated the pitch of a tone, and the number of times that sequence repeated determined the length of the tone.

Magnetic core memories were expensive to produce, amongst others because it was not possible to automate the production. All the wires had to be threaded by hand.

The illustrations that follow are by the courtesy of F. Doherty, Glasgow.

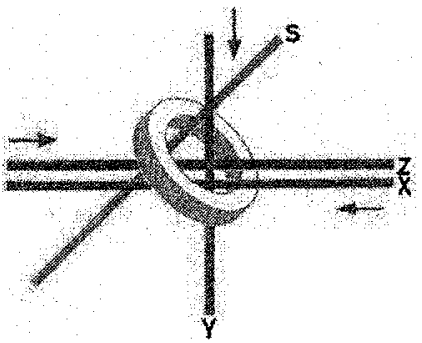

Figure 2. A Magnetic core with its control and sensing wires.

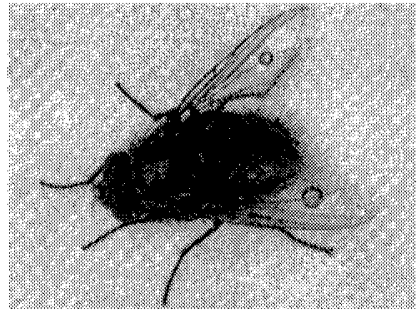

Figure 3. A 20 mil and 30 mil magnetic core on the wings of a common house fly. 